\title{
Lectin Protein Activity of Spodoptera litura After Exposured by Potential Biopesticide from Mirabilis jalapa
}

\author{
Dina Maulina ${ }^{1}$, Sutiman Bambang Sumitro ${ }^{2}$, Mohamad Amin ${ }^{3} \&$ Sri Rahayu Lestari ${ }^{3}$ \\ ${ }^{1}$ Biology Education, Faculty of Teacher Training and Education, Lampung University, Jl. Prof. \\ Dr.Soemantri Brojonegoro No. 1, Bandar Lampung \\ ${ }^{2}$ Biology Department, Faculty of Mathematics and Natural Sciences, Jl. Veteran No.1, Malang \\ ${ }^{3}$ Biology Education, Post-Graduate Program, State University of Malang
}

\begin{abstract}
This research aims to analyze the existence of lectin protein as an indicator of immunity reaction's activation Spodoptera litura after exposing biopesticide M. jalapa. Lectin test was conducted by using spot-test hemagglutination assay (HA) then was seen its speed forming of titer. The result of research shows that lectin was on the part of hemolymph $S$. litura supernatant. The result test shows that on the concentration $0.2 \%$ binding of lectin, carbohydrate and erythrocyte cells of vertebrate formed faster. The speed of titer forming was influenced by the number of hemocyte. This is caused by immulectin receptors were on the cell's surface. Therefore, exposing $M$. jalapa can induce lectin activation which functioned as the recognizing receptor of strange object which directly bound with carbohydrate related to the reaction of body immunity.
\end{abstract}

\section{Article History}

Received 18 February 2019

Accepted 24 June 2019

Keyword

Biopesticide, Mirabilis jalapa, lectin, Immunity system, Spodoptera litura.

\section{Introduction}

The best quality and quantity of agricultural yield to fulfill the need of human being is in priority scale until this recent day. However, the pests become limitation factor of the condition. The pests become resistance toward various pesticides, which affect the population boom. It is seen on the increasing resistance of agricultural pests toward various insecticides (Bai et al., 2011; Leng, 2011; Romeis, J, 2008; Shapiro, 2000). This condition is expected as the impact of using chemical (synthetic) insecticide excessively which is very dangerous and is not recommended by environment observer because can endanger the nontarget organisms (Kumar, 2012). To overcome that problem, botanical insecticide becomes one of alternatives in conserving the non-target organism in order to keep the natural balance.

The use of natural biopesticide of plant's extraction gives the secure effect (Kandagal, 2011; Nathan, 2004; Leng, 2011). Its application of use is not leave behind the chemical residue which endangers the non-target organism, human being and environment (Horne \& Page, 2008; Tanada \& Kaya, 1993). Botanical insecticide which aims as biopesticide for the 
insect's pests, one of them is the use of plant extraction Mirabiis jalapa (Maulina, 2018; Maulina, 2018; Maulina, 2018). This plant contains antiviral and antiviroid activity compounds in form of Ribosome Inactivating Protein (RIP) which is known as Mirabilis Antiviral Protein (MAP) (Vivanco, 1999). Testing of effectiveness and determining concentration of that compound are needed to prevent the resistance of target pests. The result of laboratory test which had been done by $M$. jalapa as biopesticide has $\mathrm{LD}_{50}$ on concentration $0.8 \%$ toward Spodoptera (Maulina, 2018 ${ }^{\mathrm{a}}$ ). The use of sub lethal concentration of $M$. jalapa is conducted in order the pest target is not become resistance with it. The main aim on application of biopesticide $M$. jalapa is to weaken its body immunity.

Spodoptera litura is one of dangerous pests of agricultural plants. Its folifagus characteristic can destruct the plants of yield agriculture thus makes $100 \%$ defoliation (Suharsono, 2011). Resistance of S. litura toward various chemical compound needs to be anticipated because the spreading covers South Pacific and Asia region (Sparck, T.C, 2014; Mei, Z.X, 2012; Scheiner, 2000). This becomes urgent reason to restrain spodoptera pest by using alternative effort of botanical biopesticide. Focusing on its restraint, immune system becomes the main thing that needs to be known of its whole mechanisms which occurs in its body. Therefore, biopesticide $M$. jalapa gives chance toward weakening immune system of $S$. litura.

Immune system becomes the indicator toward the death of pest. This case occurs because defense mechanism becomes the barrier of its body toward the strange object and its response when its body is getting the attack of strange object. The main task of $M$. jalapa as biopesticide is to break the defense, thus spodoptera is weakened. Generally, insect has cellular and humoral defense. Mechanism of humoral and cellular response cannot be separated one another. Both of them stimulate each other to do their role (Gillot, 2005; Chapman, 2009). Humoral response becomes the most crucial part because has the role to activate the enzyme and stimulation of strange object's recognition. In its humoral mechanism, it will stimulate immune system of running cellular. Therefore, humoral response becomes one of parameters in immunity sequence which is one of the factors that cause of its death.

This research aims to analyze how does the influence of giving leaves extract of $M$. jalapa toward the defense of humoral immune $S$. litura. The response of humoral immune which was observed is the expression of lectin protein. Lectin is protein, not enzyme or glikoprotein which binds or reacts with carbohydrate of various strange objects (Yu, QX, 2000; Yu QX, 2005; Marmaras, 2009). Lectin has very important role in defense mechanism of insect's body. Through the observation with sub-lethal concentration of M. jalapa will be seen how does the response of its humoral run. The final result of this research will determine the potential of $M$. jalapa as biopesticide toward $S$. litura pest is observed by defense mechanism of its body.

\section{Materials and Methods}

\section{Sample of Research}

This research used larva S. litura the fourth instar as sample of research. Larva S. litura was obtained by Balai Penelitian Tanaman Pemanis dan Serat (BALITTAS) Malang, East Java. The process of multiplication and treatment of larva was conducted at laboratory of plant pest with the condition of temperature $25-26^{\circ} \mathrm{C}$ and humidity $50-55 \%$. During the process of larva multiplication was given woof diet of darker colored mustard greens and was 
treated inside of plastic topless (volume 5 liter, diameter $12 \mathrm{~cm}$ and height $11 \mathrm{~cm}$ ). Each topless contains 50 larva of $S$. litura and the topless of treatment was cleaned every 12 hours. Furthermore, hemolimf of research sample was used as the subject of research for the content of lectin protein.

\section{Extract of $M$. jalapa Biopesticide}

The crude extract of $M$. jalapa was obtained through maceration process which conducted at UPT Materia Medica Batu-Government Health Service of East Java Province. The leaves of $M$. jalapa were obtained from field searching at Lampung province. The leaves of M. jalapa was dried without sunlight. Meseration was conducted by using ethanol $96 \%$ during 3 days. The result of this maseration collection was done further on evaporation process until it formed the paste. The paste was in concentration $100 \%$.

This research was used sub-lethal concentration were $0.1 \%, 0.2 \%, 0.4 \%, 0.8 \%(\mathrm{w} / \mathrm{v})$, and the control. In this study, \% (w/v) is defined as the percent of weight of $M$. jalapa extract (in gram) in the total volume of solution (100 $\mathrm{ml}$ ethanol). M. jalapa extract having certain concetration was sprayed throughout the surface of green mustard feed. After $24 \mathrm{~h}$ of exposure, hemolymph of the larvae were taken for the immune system measurements. The treatment was implemented individually on each larva, and was replicated on five different larvae for each condition.

\section{Lectin Analysis}

Hemolimf S. litura was collected in tube eppendorftube which had been filled by crystal phenylthiourea (PTU). The solution was centrifuged during 5 minutes with temperature $4^{\circ} \mathrm{C} ; 800 \mathrm{~g}$ then pellet and supernatant were separated on different epperndorftube. Supernatant was used for Hemagglutinin-Assay (HA) test, pellet was washed by using TBS $\mathrm{pH}$ 7.4. Then, $50 \mathrm{ul}$ TBS and pellet were suspended with speed $12.000 \mathrm{~g}$ during 15 minutes, the result of centrifugal deposits was used for HA. Hemolimf $2 \mathrm{ml}$ was homogenized in the pressure $400 \mathrm{kp} / \mathrm{cm}^{2}$ during 5 minutes, was continued by centrifuging in the speed $12.000 \mathrm{~g}$ during 15 minutes, this supernatant was used as lectin source.

Hemagglutination assay test was conducted by preparing blood of vertebrate animals with its anticoagulant. Wash 3 times TBS pH 7 concentration 2\%, prepare test container (titertek) " $v$ ", put in test sample as much $24 \mu \mathrm{m}$ (centrifugal deposits) in TBS pH 7,4, drip $25 \mu \mathrm{m}$ erythrocyte suspense and was incubated with room temperature during 60 minutes (Suryani, 2014).

\section{Results and Discussion}

Immune system of insect is the result sequence of defense body toward specific and non-specific response toward detected strange object of its body. The defense mechanism of insect covers cellular and humoral defense. Humoral response holds the main role in the sequence of immune system through various enzymatic and non-enzimatic reaction which has the role in recognizing the body toward strange object and its resistance effort. The mechanism depends on recognition effort of strange object through its receptor. There are 8 receptors which involved in mechanism of humoral immune, namely: immulectins, Thioestercontinuing proteins (TEPs), LPS-binding protein, Peptidoglican recognitions proteins (PGRPs), Gram-negative bacteria binding protein (GNBP), $\beta$ 1,3-glukan recognition protein ( $\beta G R P)$, Haemolin (immunoglobulin superfamily) and B. mori multibinding protein (BmMBP). Induction of strange object which is received by these receptors will give the impact to the 
action, such as: (1) induction and secretion of anti microbial peptides (AMPs); (2) mechanism of melanization (Marmaras, 2009).

Receptor becomes the important part in defense mechanism. Lectin is protein which acts as recognizing receptor of strange object which binds directly with carbohydrate (Yu QX, 2005). Its existence becomes the main key to activate phenoloxidation on hemolimf plasma (Yu, QX, 2000; Yu QX, 2005; Marmaras, 2009). Immulectin lies in granular and eonocytoid cell also has function in increasing encapsulation (Yu QX, 2004). Its ability in recognizing strange object as its non-self in form of glycoprotein and glycolipid makes it as the main receptor in mechanism of immune system. Lectin that able to induce the sequence of cellular and humoral in defense system becomes the indicator for recognizing strange object and for further signal transduction.

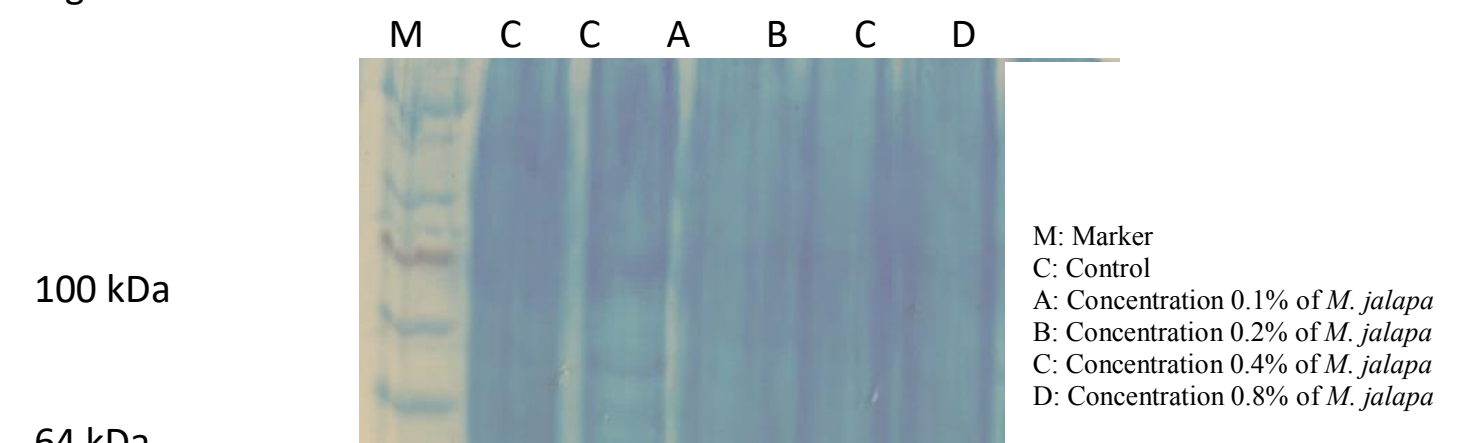

Figure 1. The profile of Spodoptera litura lectin protein

Result of research showed that lectin protein existed in S. litura when was exposing biopesticide $M$. jalapa. This is shown by the profile of lectin protein which has molecule weight in $40 \mathrm{kDa}$. Figure 1 is the result of electrophoresis test of hemolimf $S$. litura in part of supernatant. The speed of lectin response was measured through the form of hemaglutination assay (HA) measurement ability (titer) which showed different result on each given concentration. Test of HA which was conducted observes the lectin response toward its binding with membrane cell of blood of vertebrate animals (carbohydrate). There are 4 concentrations of sub-lethal $M$. jalapa which were exposed in larva S.litura, namely: $0.8 \%$, $0.4 \%, 0.2 \%$ and $0.1 \%$. Test result shows that on concentration $0.2 \%$ lectin binding with carbohydrate and erythrocyte cell of vertebrate were formed faster than the control (figure 2).

Forming of HA measurement ability (titer) on the control occurred in the eightieth minutes while concentration $0.1 \%$ and $0,2 \%$ occurred faster in the sixtieth minutes (figure 1 ). The speed of measurement ability (titer) forming was influenced by many hemocyte, because the receptor of immulectin was on the surface of its cell, thus the more number of hemocyte, then the number of lectin receptor will more increase and the activity of lectin binding with strange object will be faster to be recognized. Concentration $0.2 \%$ is the optimum concentration of immune system's mechanism which was shown by the increasing number of hemocyte $(P<0.05)$ (Maulina, 2014; Suryani, 2014). 
Giving of $M$. jalapa on the concentration $0.4 \%$ and $0.8 \%$ gave longer time response than in the control, they were in the ninetieth minutes and in the hundredth five minutes. This was expected because of more decreasing number of hemocyte. On the higher concentration, hemocyte cells cannot proliferate anymore. Toxicity of high concentration causes enzymatic and coordination system disturbance thus cells which induced the cell mitosis are obstructed (Maulina, 2013).

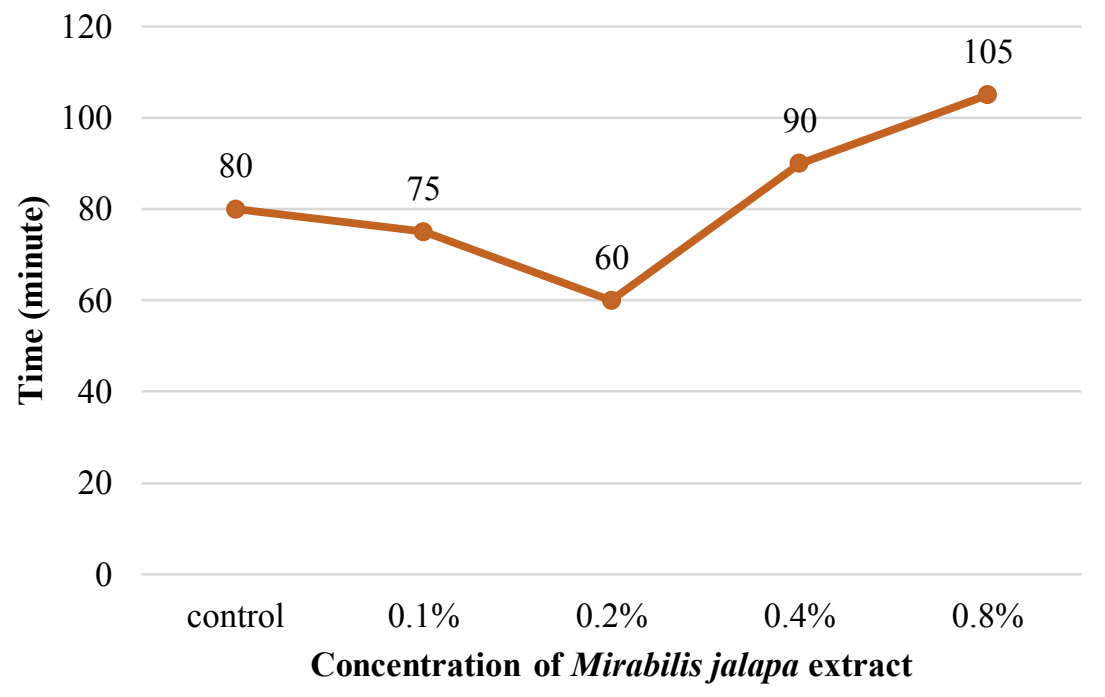

Figure 2. Speed of Forming Hemaglutination

In principle, the application of biopesticide $M$. jalapa is not kill the target pest S. litura totally but its use can induce the reaction of immune system by lowering the physiological function at the whole (Maulina, 2014). This condition is intended on the preventive efforts of sustainable resistance of target pest. The prevention of resistance is needed in order to be done easier for the control of this pest. If resistance occurs, resurgence will occur certainly because there is a multiplying use of insecticide doses (Spark, 2015; Dutcher, 2007). Therefore, the use of biopesticide $M$. jalapa prevents both of cases occur based on the principle recommendation of Integrated Pest Management (IPM) (Kumar, 2015; Kather, 2012; Kumar, 2012; Kandagal, 2011; Leng, 2011; Nathan, 2004). The result of this research can be used as basic reference in using biopesticide $M$. jalapa to apply widely in agricultural land. Setting the amount of spodoptera pest needs the consideration in the proper concentration in applying on the actual agricultural land. The aim of weakening immune system which was conducted in this research ends on the mortality of target pest thus can be used to control the population of pest.

\section{Conclusions}

Mirabilis jalapa has the potential as biopesticide, the indicator was seen through mechanism of humoral immune system of larva Spodoptera litura body. The result of analysis is seen that the given leaves' extract of $M$. jalapa can induce the activity of lectin protein. Giving the concentration $0.2 \%$ of $M$. jalapa extract able to induce the speed of lectin forming reaction, this condition stimulates the occurrence of weakening sequence of immunity process of S. litura. 


\section{Acknowledgement}

We express our deepest gratitude to Directorate of Research and Community Service, Directorate General Strengthening Research and Development and Ministry of Research, Technology and Higher Education who have provided the research grants for this doctoral dissertation research in accordance with the research contract, number: 062/SP2H/LT/DRPM/2018.

\section{References}

Anggraeni, T., Melanie. \& Putra, R. E. 2011. Cellular a Humoral Immune Defenses of Oxya japonica (Orthoptera: Acrididae) to Entomophathogenic fungi Metharizium anisopliae. Enthomological Research, 41, 1 - 6.

Ashida M \& Brey P. 1997. Recent advances in research on the insect prophenoloxidase cascade. Molecular Mechanisms of Immune Responses in Insects (ed. by P Brey \& D Hultmark), pp. 135-171. Chapman \& Hall, London, UK.

Bai, Y., Yan, R., Ke, X., Ye,G., Huang, F., Luo, Y., \& Cheng, J. 2011. Effect of Transgenic Bt Rice on Growth, Reproduction, and Superoxide Dismutase Activity of Folsomia candida (Collembola: Isotomidae) in Laboratory Studies, Journal Economic of Entomology, 104, 1892 - 1899.

Boman, H. G. 1986. Antibacterial immune proteins in insects. Immune Mechanisms in Invertebrate Vectors (ed. by AMLackie), pp. 45-58. Symposia of the Zoological Society, London, UK.

Cerenius, L \& Soderhall, K 2004. The prophenoloxidase-activating system in invertebrates. Immunological Reviews 198: 116-126.

Chapman, R. F. 2009. The Insect Structure and Function $4^{\text {th }}$ Edition. Cambrigde University.

Dutcher, J. D. 2007. A review of Resurgence and Replacement Causing Pest Outbreaks in IPM. General Concept in Intergrated and Disease Management, 27-43. Entomology Departement, University of Georgia, Tifton GA, USA.

Gillot, C. 2005. Enthomology Third Edition. University of Saskatchewan- Springer.

Gonzales, I., Santoyo, \& Aguilar, A.C. 2011. Prophenoloxidase: A Key Component of The Insect Immune System, Journal of Entomologia Experimentalis et Applicata, 142, 1 - 16.

Horne, P. A. \& Page, J. 2008. Integrated Pest Management for Crops and Pastures, Victoria: Landlink Press.

Kandagal, A. S. \& Khetagoudar, M. C. 2011. Study on Lavarsidal Activity of Weed Extract Against Spodoptera litura. Journal of Environmental Biology. Vol. 34, 253-257.

Kather, H. F. 2012. Prospect of Biopesticides in Insect Pest Management. Journal Pharmacologia. Vol. 3 (12): 641-656. Doi: 10.5567/phrmacologia.2012.641-656.

Kumar, S. \& Singh, A. 2015. Biopesticide: Present status and Future Prospect. Journal Fertilizer and Pesticide. Vol. 6 (2). Doi: 10. 4172/jbfbp. 1000e129.

Kumar, S. 2012. Biopesticide: A Need for Food and Evironmental Safety. Journal Biofertilizer and Biopesticide. Vol. 3 (4). Doi: 10.41772/2155-6202. 1000e107.

Leng, P., Zhang, Z., Pan, G. \& Zhao, M. 2011. Applications and Development Trens in Biopesticide. African Journal of Biotechnology. Vol. 10(86), pp. 19864-19873.

Marmaras, V.J. \& Lampropoulou, M. 2009. Regulator and Signaling in Insect Haemocyte Immunity, Departement of Biology, University of patras, Journal of Cell Signaling, 17, 8-16. 
Maulina, D \& Anggraeni, T. 2014. The Effect of The Combination of Two Biological Control Agents, Mirabilis jalapa and Bacillus thuringiensis, to Spodoptera exigua's Immune Respons and Their Mortality. AIP Confference Proceeding-International Conferences Mathematics and Sains: Bandung.

Maulina, D., Sumitro, S. B., Amin, M., Lestari, S. R. $\left(2018^{\mathrm{a}}\right)$. Identification of bioactive compounds from Mirabilis jalapa L. (Caryophyllales: Nyctaginaceae)extract as biopesticides and their activity against the immune response of Spodoptera litura F.(Lepidoptera: Noctudiae). Journal of Biopesticides, 11(2): 89-97.

Maulina, D., Amin, M., Lestari, S. R.,\& Aziz, M. (2018 ${ }^{\text {b }}$. Alanine as natural biopesticide from Mirabilis jalapa and its interaction with glutamate as an inhibitor in insects immune system. Journal of Biological Researches, 23(2): 77-83. DOI: http://dx.doi.org/10.23869/bphjbr.23.2.20185.

Maulina, D., Sumitro, S.B., Amin, M., Lestari, S. R. (2018c). Identification of Peptides Compounds from Mirabilis jalapa L. (Caryophyllales: Nyctaginaceae) Potentially as a Biopesticide. J. Phys.: Conf. Ser. 1093 (2018) 012009. DOI: 10.1088/17426596/1093/1/012009.

Mei, Z. X., \& Qiu, H. B. 2002. Insecticide resistance of the Common Cutworm (Spodoptera litura) and Its Control Strategies. Enthomological Knowledge. http://www.cnki.com.cn

Nappi A.J. \& Christensen B.M. 2005. Melanogenesis and associated cytotoxic reactions: applications to insect innate immunity. Insect Biochemistry and Molecular Biology 35: 443-459.

Nathan, S. S., Chung, P. G., \& Murugan, K. 2004. Effect of Botanical Incecticides and Bacterial Toxin on the Gut Enzyme of the Rice Leaffolder Cnaphalocrocis medinalis. Journal of Phyparasitica. Vol. 35 (5): 433-443.

Romeis, J., Bartsch, D., Bigler, F., Candolfi, M. P., \& Gielkens, M. M. C. 2008. Assesment of Risk of Insect-Resistant Transgenic Crpos to Nontarget Arthropods. Enthomology Publications. IOWA State University.

Schreiner, I. 2000. Cluster Caterpillar (Spodoptera litura [Fabricius]), Agricultural Pest of The Pacific ADAP.

Shapiro, M. 2000. Enchancement in activity of Homologus and Heterologus Baculoviruses Infectious to Beet Armiworm (Lepidotera: Noctuidae) By an Optical Brighttener, Journal of Economic Enthomology, 93, 572 - 576.

Sparck, T.C \& Nauen, R. 2014. IRAC: Mode of Action Classification and insecticide resistance. Pesticide Biochemistry and Physiology, 121 (2015) 122-128

Suharsono. 2011. Sensitivity of Tolerant Soybean Strains Saturated with Water toward Spodoptera litura F. Research Center of Legumes and Tubers.

Suryani, I \& Anggraeni, T. 2014. The Effect of Leaf Biopesticide Mirabilis jalapa and Fungi Metarhizium anisopliae to Immune Response and Mortality of Spodoptera exigua Instar IV. AIP Proceeding-International Conferences Mathematics and Sains : Bandung.

Sussman, A. 1949. The functions of tyrosinase in insects. Quarterly, Review of Biology 24: 328-341.

Tanada, Y \& Kaya, H. K. 1993. Insect Pathology. Academic Press, INC-Harcourt Brace Jovanovich, Publishers. 
Vivanco, M. J. 1999. Antviral and Antiviroid Activity of MAP-Containing Extracts from Mirabilis jalapa Roots, Plant Diseases, Department of Plant Pathology and Biotechnology Institute, University Park.

Wyatt G. 1961. The biochemistry of insect hemolymph. Annual Review of Entomology 6: 75102.

Yu QX. 2004. Immulectin-2, a pattern recognition receptor that stimulate hemocyte encapsulation and melanization in the tobacco hornworm, Manduca sexta, Journal of Dev Comp Immunol, Jull 1,28 (9): 891-900. DOI: 10.1016/j.dci.2004.02.005.

Yu QX. 2005. A Novel C-type immulectin-3 from Manduca sexta is translocated from hemolimph into the cytoplasma hemocyte, Journal of Insect Biochem Mol Biol, Apr, 35 (4): 285-95. DOI: 10.1016/j.ibmb.2005.01.004.

Yu, QX. \& Kanost, M. R. 2000. Immulectin-2, a Lipopolysaccharide-spesific Lectin from an Insecat, Manduca sexta, Is Induced in Response to Gram negative bacteria. Journal of Biological Chemistry. Vol : 275, 37373-37381. Doi: 10.1074/jbc.M003021200. 